\title{
A Book Review of Duchologia polska. Rzeczy i ludzie w latach transformacji by Olga Drenda
}

Author: Olga Drenda

Publisher: Wydawnictwo Karakter

Release Date: 2016

Number of Pages: 256

\section{Marek Jeziński}

Nicolaus Copernicus University in Torun jezmar@umk.pl

Received 10 September 2017; accepted 28 October 2017.

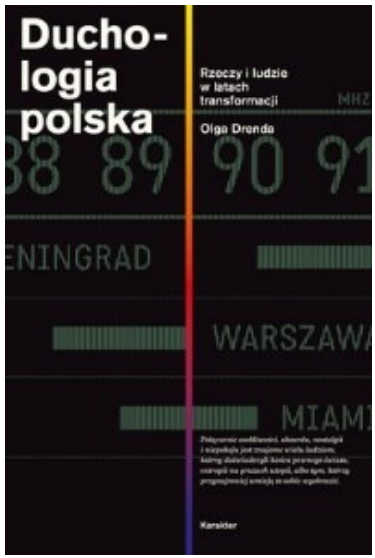

1.

The book by Olga Drenda Duchologia polska. Rzeczy i ludzie w latach transformacji, whose title can be rendered in English as Polish Hauntology: Things and People in the Transformation Period, is a kind of anthropological travel in time: to the past that is not too distant, that is still remembered, and still visible in Polish streets. The work covers the "haunted time" between 1987 and 1994, when Polish society underwent significant social, cultural, economic and political changes, joining liberal democracies and liberal free market economies. Drenda depicts several phases of the transition, related to the ineffectiveness of the socialist system, political changes towards democracy (with the Round Table Agreements and semi-free elections of 1989 as the landmarks of this process), and the gradual adaptation to a new social system. Focusing mostly on the changes in the cultural sphere, the author argues that the process of adaptation was over in 1994, when the copyright law was introduced in Poland.

Drenda uses the concept of "hauntology" to depict the process of people's trying to come to terms with the new world and its complexity. In the book Specters of Marx by Jacques Derrida (2006, first published in 1993; 2008), the French philosopher refers to the presence of memories, fragments of the past events, or the occurrence of themes from the past in 
contemporary cultural practices. This approach has been debated and discussed in numerous books and comments, for example, in the works by Colin Davis $(2005,2007)$, Fredric Jameson (2008), Nicholas Royle (2003), or in the texts gathered in Maria Pilar Blanco and Esther Peeren's The Spectralities Reader: Ghosts and Haunting in Contemporary Cultural Theory (2013). In some of these analyses, hauntology is viewed as a liminal phenomenon in between certain stages, having an incomplete, indefinite character. This aspect is discussed by Drenda in her book.

The past as a phenomenon "haunting" the present is a motif found in every culture and in every historical period: this primarily refers to tradition and the way in which the elements of culture from the past define the present. This is one of the bases on which a group culture is formed: a group's identity is perceived in terms of continuity necessary to maintain the main values defining the specific character of a given society. As Simon Reynolds in his widely acclaimed book Retromania (2011) points out, such a recurrence of the past in the present, "visited" by the ghosts of the bygone years is particularly visible in the first decades of the $21^{\text {st }}$ century. Reynolds calls the present times in pop culture "the Re-decade" characterized by intentional and frequent references to the past in popular music and the more or less creative ways of using bygone inspirations by contemporary artists. In this perspective the past becomes the main paradigm through which people interpret today's culture. Being embedded in the past and in tradition is typical for human societies: individuals and groups in their cultural practices try to reproduce the social order that gives them stability and predictability in everyday life.

As Nick Couldry points out in Inside Culture: Re-imagining the Method of Cultural Studies (2000), to describe and capture the changes of the cultural system, the system itself or at least its parts must be "closed" and the cultural phenomena related to the change completed. Understandably, culture is not a measurable phenomenon; it can be examined by researchers by decoding a spectrum of interconnected elements interwoven into cultural narratives. In her book, Drenda shows this period of Polish history as a closed and already completed transformation of fundamental importance. The period between 1987 and 1994 is the time in which the subsequent stages of the fall of the Polish People's Republic's (PRL) political system (something that seemed impossible only five years earlier) took place and the new patterns of behaviour emerged. Importantly, the political transformation that was experienced in Poland was a process of continuous adaptation and assimilation of cultural patterns. It turned out, however, that the new system was different from the one the majority of Poles expected and dreamed about during the decades of socialist power: real life in capitalism was mainly reduced to struggle with everyday life difficulties. In other words, using Max Weber's concept, systemic modernization took place in Poland, and today one can experience its testimonies or remnants as ghostlike - hauntological—afterimages.

The period between 1987 and 1994 is still present in the cultural practices of Polish people: the references to the 1980 s and 1990 s are, to some extent, the essential components of the group identity dominant in the first decades of the $21^{\text {st }}$ century (due to the fact that the current adult generation was growing up in these decades), following the cultural retro or 
vintage trends prevailing in Europe nowadays. Tradition is generally attributed with positive values and supplemented with nostalgia, through which the past is consistently mythologized. The main value of Drenda's book is that it shows the reader that the past, to which contemporary culture constantly refers, may be disturbing, and that the "haunting" of the present is not and cannot be understood only in positive terms. Looking from this perspective, the past is a source of anxieties, fears, and understatements. The book's title Polish Hauntology emphasizes that remembering the past is not a pleasant journey in time, but an attempt to deal with what in today's culture appears to be a set of disruptions, which "hurt" and still require proper explanations.

The book by Drenda is an attempt to "deal" with such ghosts and fears of the transformation period and its complexity. The author assumes in the "Introduction" (Drenda, 2016, pp. 7-8) that to overcome such anxieties one needs to tell the others about the phenomena that cause fear. Additionally, as the author notes, "memories of the $80 \mathrm{~s}$ and $90 \mathrm{~s}$ are full of disturbances. Of course, this is their very nature, prone to forgeries and deceptions - but why is there so much of technology-driven horror in generational memory? Is it because we remember a picture full of 'ghosts,' afterimages, and ruptures. . .?" (Drenda, 2016, pp. 7-8; my translation).

2.

The past is generally remembered as a set of colourful memories captured on postcards and pictures/photos from the era. Such categories as "pictures"/ "photographs" and "afterimages" organize the argument in Drenda's book: they are not only material artefacts and non-material images in people's minds that evoke memories and determine their strength, but also the means through which Drenda segregates, arranges, and categorizes the materials. Looking at photos, posters and postcards - and all visual documentation in generalDrenda tells a story, which sometimes strays from the path of anthropological study and takes the form of a reportage about the search for the lost world, which exists next to us. Its habitats can be found in the archives of public institutions, but also in people's memory and home drawers, housing memorabilia. The subsequent chapters of Drenda's book are devoted to various hauntological phenomena: urban spaces (the chapter "Krakowskie Przedmieście is flooded with sunshine"); the housing styles (the part "Cosily"); the design of everyday objects and toys (the section "The Bear who lost to the Frog"); electronic equipment and the distribution of the media containing music and feature films (the fragment "Stereo Super Quality"); the art of covers and posters, which was developed in the earlier period, but in the era of transformation was replaced by ineffective cheap graphic design (the chapter "Foil-wrapped butterflies"). Further chapters comment on the "invasion" of aggressive advertising in the public sphere and in the media (the section "A girl

\footnotetext{
${ }^{1}$ All chapter titles in English with the exception of "Stereo Super Quality" are my translation.
} 
in an advertisement adds prestige and elegance"); a growing fascination with esoteric issues - books, magazines and television programmes about the "hidden dimension" of reality (the part "Purple turning white"); and finally, Poles' fascination with the Western lifestyle and products that began to be available on the Polish market, as the "Western" label was supposed to guarantee their superior quality (the chapter "Michael will eat cheesecake with relish").

Drenda's book should be praised for its documentary content: the author evokes many anecdotes, stories, and recollections told by people who lived in the realities of the transformation period in Poland and the foreigners travelling around this part of Europe. This aspect of the book is particularly valuable: people who remember the living conditions during that period may recall the "surrealism" of real socialism and the precarity of the transition phase, and probably many readers often thought: "oh, really indeed! That's how it was. .." when reading the book. For the young people Duchologia polska may be an important lesson in the history of their parents' and grandparents' generations. The Polish People's Republic had an inefficient economic system and today's stories about it focus on the systemic curiosities and absurdities. It must be remembered, however, that the reality Poles had to live in was neither surreal nor fun. It is worth looking at such curiosities from that time as curtains in shop windows, foreign currency stores, local bazaars as the places of basic products supply, or physical space shortage in flats, buildings and pavilions which were inadequate to human needs. One can add the poor aesthetic quality of books, tapes, and magazines covers of the transformation period. The anecdotes concerning these phenomena abound in the book and are attractive for a reader.

The stories spun by Drenda, then, expose the specificity of the times of the Polish People's Republic and the paradoxes of its functioning. Ironically, although its political system was negatively assessed by the majority of Poles, it introduced into social and cultural life several phenomena that define cultural identity of today's Poland. One faces a peculiar contradiction here: the citizens who lived in tough conditions and regularly criticized the authorities were characterized by outstanding creativity, supported by-which is extremely interesting - the media institutions controlled by the politicians. In response to the inadequate supply in shops, ineffectiveness of trade, difficulties with obtaining objects of everyday use (kitchen equipment, furniture and interior furnishings, clothes), articles in the magazines and journals controlled by the communist party were published, containing advice on cooking, tailoring, the construction of furniture or recycling. The political system could not officially admit its own inefficiencies and general ineffectiveness, and at the same time, it showed its citizens that they could overcome the difficulties by themselves. The beginning of the 1990s was an obvious qualitative breakthrough: Western culture and its products appeared on the market, which began to be organized on the supply and demand basis. The changes were accompanied by the emergence of large-scale unemployment, a decline in real income and a significant poverty of some social groups, which was described by sociologists in terms of social exclusion and underclass. Therefore, only a small number of Poles could afford full participation in consumption (the possibility of 
buying goods available on the market) as the purchasing power of most citizens was drastically limited. This resulted in many cases of abuse, scams, scandals, and "one-season" careers in business and politics; the period is remembered by many people through these negative phenomena. Tricking the system by citizens was a semi-acceptable practice in the socialist times; after the turn of 1989/1990, social acceptance for such activities began to disappear, and from the mid-1990s the "wild capitalism" began to "get civilized," and the goods which previously could be purchased only for foreign currency in special shops (e.g. Pewex, Baltona) and which were often the object of Poles' dreams (the electronic equipment of well-known producers, original Western clothes, such as jeans, shirts, denim jackets) became easily available in ordinary stores.

In her book, Drenda adopts the ethnomethodological approach, using the evidence of material culture and supplementing it with references to the recollections of culture users. Posters, photos, films, documentaries, TV programmes, commercials, popular books, newspaper articles of the era are the testimonies of the market changes that were taking place during this difficult period. What is important for today's researcher, these testimonies of culture are also perceived as the sites of haunting. Drenda successfully shows that despite the fact that Poland was not a friendly place to live at that time, it looks stylish and appealing in the nostalgic memories of people, films and articles in the press from today's perspective. Captured on the photographic films of the East German company ORWO, the pictures depicting this period are saturated with special colours, creating a unique and completely "unreachable" world.

3.

The range of topics discussed by Drenda in the book is broad, although — obviously — she does not claim to present a complete picture of the declining state regime. The list of topics missing from the book, but important in my opinion, embraces: the counter-cultural content of popular music, music videos as a form of registering selected aspects of reality and reflecting their changes, the transformations of youth subcultures (e.g. Depeche Mode fans, grunge, and The Cure fans), or Poles' fascination with television and its products: TV quiz shows (Blind date, Wheel of Fortune) and TV series of domestic (e.g. Alternatywy 4, Zmiennicy, W labiryncie) and foreign production (e.g. In the Stone Circle, Allo, Allo!, Dallas and Dynasty). This last aspect is mentioned in the book but should be given more space. A separate chapter could be devoted to the media addressed to children: TV programmes, magazines and journals. This was a unique cultural space in which Miś Uszatek (the children's TV series produced during the communist times) was suddenly replaced by Disney studio's Duck Tales (and later by Pokemon), and Świerszczyk (a children's magazine) was succeeded by Donald Duck, so that the Polish native patterns and values were being substituted by globalizing culture trends adopted mainly from the USA. 
Despite its merits, Drenda's book might leave a reader with more academic interests somewhat unsatisfied. The tradition of local knowledge, used after Clifford Geertz (the ethnography of everyday life and meanings, which real users of culture attribute to the studied phenomena in a given place and time), is confronted in Drenda's book with ethnomethodological research concerning cultural practices of Poles during the analyzed period. Thus, it would be worth showing this theoretical approach also in the context of gaining soft data (after all, "memory studies" as a form of biographical method and content analysis is based on such a methodological approach), as it has a meaningful impact on the research area the author deals with. Hence, the necessity of employing such sociological, cultural, and anthropological categories as the clash of cultures, the assimilation of values and patterns of behaviour, acculturation/counter-acculturation, cultural distance, or culture shock, which are absent in the volume. I believe that the whole argument would benefit from such anthropological categories, without losing its clarity.

4.

The book by Olga Drenda represents a larger cultural tendency of interest in the end of the period of socialist Poland and the transition to capitalism and democracy, which includes publications by historians, popular-science books, documentaries, computer and traditional games (board and strategic ones) and a whole range of everyday objects and clothes based on "straight from the Polish People's Republic" design. Naturally, in the phenomenon labelled as the "PRL cult" the internet environment plays the most important role: the memories of that time are present in the Polish internet discourse on the websites, entries on forums, blogs/photoblogs containing film videos, photographs and music video clips from the era. Polish hauntology is a way of remembering, expressed in the mythologization of the past, which cannot be assessed unambiguously, but is recalled with nostalgia, often without reflection over the nature of the cultural phenomena it refers to. In such a discourse, however, it is not the balanced assessment that comes out as a result of cultural analysis: the end of the socialist system and the period of political transformation still induce emotions and evoke memories. Olga Drenda's book is a valuable voice in the discussion on this phenomenon, as it captures a part of these responses. It shows in a successful, though perhaps incomplete way, that events, people, places and objects stored in old photographs and memories may create a unique cultural experience.

\section{References}

Couldry, N. (2000). Inside culture: Re-imagining the method of Cultural Studies. London, UK: Sage Publications.

Derrida, J. (2006). Specters of Marx: The state of the debt, the work of mourning and the new international. New York, NY: Routledge. 
Derrida, J. (2008). Marx and sons. In M. Sprinker (Ed.), Ghostly demarcations: A symposium on Jacques Derrida's Spectres of Marx (pp. 213-269). London, UK: Verso.

Davis, C. (2005). État Présent: Hauntology, spectres and phantoms. French Studies, 59(3), 373-379.

Davis, C. (2007). Haunted subjects: Deconstruction, psychoanalysis and the return of the dead. Basingstoke, UK: Palgrave Macmillan.

Jameson, F. (2008). Marx's purloined letter. In M. Sprinker (Ed.), Ghostly demarcations: A symposium on Jacques Derrida's Spectres of Marx (pp. 26-67). London, UK: Verso.

Pilar Blanco, M., \& Peeren, E. (Eds). (2013). The spectralities reader: Ghosts and haunting in contemporary cultural theory. London, UK: Bloomsbury.

Reynolds, S. (2011). Retromania: Pop culture's addiction to its own past. New York, NY: Faber \& Faber.

Royle, N. (2003). The uncanny. Manchester, UK: Manchester University Press. 